Egyptian Journal of Aquatic Biology \& Fisheries

Zoology Department, Faculty of Science,

Ain Shams University, Cairo, Egypt.

ISSN $1110-6131$

Vol. 23(5): 67- 80 (2019)

www.ejabf.journals.ekb.eg

\title{
Molecular Phylogenetic Linkage for Nile and Marine Puffer Fishes Using Mitochondrial DNA sequences of Cytochrome b and 16S rRNA
}

\author{
Zeinab A. Mar'ie ${ }^{1,2}$ and Mohammad Allam ${ }^{1}$ \\ 1- Zoology Department, Faculty of Science, South Valley University, Egypt. \\ 2- Science Department, Faculty of Education, Hurghada, South Valley University, Egypt. \\ Corresponding author: Mohammad_allam10@sci.svu.edu.eg
}

\section{ARTICLE INFO \\ Article History: \\ Received: Sept. 3, 2019 \\ Accepted: Nov. 28, 2019 \\ Online: Dec. 2019}

\section{Keywords:}

Tetraodon lineatus

Arothron hispidus

Molecular Phylogenetic

Cytochrome b

16S rRNA

\begin{abstract}
Based on two mitochondrial DNA sequences; cytochrome $b$ and 16S rRNA with using a total DNA template from muscle tissues of two puffer fishes species Arothron hispidus and Tetraodon lineatus, our study was performed to reveal a general view about the phylogenetic linkages among River Nile Tetraodon lineatus and Red Sea Arothron hispidus to other marine puffer fishes. The nucleated sequence lengths based on cytochrome b gene in Arothron hispidus and Tetraodon lineatus were (337 and 367 bp. respectively), while using the 16S gene in Arothron hispidus and Tetraodon lineatus revealed nucleated sequence of length (186 and 237 bp. respectively). The sequenced regions of cytochrome b in Arothron hispidus and Tetraodon lineatus were submitted in the GenBank/NCBI under accession numbers MN186251 and MN186252 respectively, also the sequenced regions of $16 \mathrm{~S}$ in Arothron hispidus and Tetraodon lineatus were submitted in the GenBank/NCBI under accession numbers MN186287 and MN175976 respectively. The phylogenetic linkages were designed using three phylogenetic methods; Maximum Likelihood (ML), Neighbour Joining (NJ) and Minimum Evolution (ME). The Pairwise genetic distances of both (cyt-b) and (16S) illustrated that, the Nile puffer fish Tetraodon lineatus was closely related to marine puffer fishes of genera Arothron and Canthigaster more than other marine puffer fish genera. Our results showed high efficiency of cyt-b and 16S rRNA in the phylogenetic analysis, so we strongly support the usefulness of them for taxonomy studies of puffer fishes.
\end{abstract}

\section{INTRODUCTION}

Puffer fishes or blow fishes, are named due to their capability to inflate their bodies due to pull the water into the abdomen, or air when they found out of the water, tough scale less skin often with small spindles, jaws with break-like dental plates having a medium structure, a small slit-like gill opening (Randall, 1982). Puffer fishes are among the most poisonous vertebrates in the world, many parts of the body contain toxin tetrodotoxin and one highly toxic to most animals when eaten (McClane, 1977). Sabrah, et al. (2006) reported that, the puffer fishes are widespread in the Red Sea and about 120 species of them are mostly distributed in tropical seas. They also called blowfish and globefish, due to their ability of expanding their bodies with water or air when intimidate, and become difficult to swallow. Brenner et al. (1993) said that the genome of puffer fishes seem to be uniquely compact, because it includes unusually small introns and lack extensive repetitive sequences and pseudogenes. However, the puffer fish genome preserves the structural complexity reflected in the intron and exon arrangements observed in homologous genes of higher vertebrates (Elgar et al., 1996 and Koop and Nadeau, 1996) and has become 
a common model for sequencing and mapping the genomes of higher-taxa vertebrates (Song et al., 2001).

Tetraodontiform lineages posses' extremely compact genome among the smallest of all vertebrates (Hinegardner, 1968 and Brainerd et al., 2001), puffer fishes became a major model organism in vertebrate genomics, where Takifugu rubripes and Tetradon nigroviridis became the first non-human vertebrates to have their complete genomes sequenced (Brenner et al., 1993 and Jaillon et al., 2004). Comparative study for the gene sequences of puffer fish and other related species can furnish the help to knowledge the answer for genome structure and evolution (Kai et al., 2003). Pepe et al. (2005) reported that, the improvement of molecular biological techniques may solve problems about fish identification through enabling forthright analysis for the nucleotide sequences of either nuclear or mitochondrial DNA.

In fishes, Karaiskou et al. (2003) estimate the phylogenetic linkages among some species of genus Trachurus using partial sequences of cyt-b and the 16S rDNA gene. The mitochondrial cytochrome $b$ (cyt-b) and 16S rRNA (16S) DNA sequences are among the very widely used genetic markers in fish species identification and have been employed for population genetic studies (Peng et al., 2004; Kartavtsev et al., 2007; Kochzius, 2009 and Teletchea, 2009).

Within many mtDNA genes, cytochrome b has been widely used to estimate the genetic variation and inferring phylogenetic relationships (Irwin et al., 1991; McVeigh and Davidson, 1991; Johns and Avise, 1998; Callejas and Ochando, 2000 and Bajpai and Tewari, 2010).

The 16S ribosomal RNA, a component of the $30 \mathrm{~S}$ small subunit of the mitochondrial ribosome in vertebrate, has been reported $1640 \mathrm{bp}$. long in fish (Naock et al., 1996), which is highly conserved. The mitochondrial (16S) gene is very commonly used to examine the phylogenetic linkages of fishes at different taxonomic levels (Faddagh, et al., 2012). Segments of sequence of this region are efficiently used for constructing phylogenies (Singh et al., 2015).

The primary target of this work was to reveal the phylogenetic relationships of Nile puffer fish Tetraodon lineatus and Red Sea Arothron hispidus to other marine puffer fishes, using Mitochondrial DNA sequences of Cytochrome b and 16S rRNA. Additionally, we used three phylogenetic methods; Maximum likelihood (ML), Neighbour Joining (NJ) and Minimum Evolution (ME) to compare results with more widely used methods.

\section{MATERIALS AND METHODS}

\section{Collection of the samples:}

The puffer fishes of two genera; Arothron and Tetraodon belong to Family Tetraodontidae, Order Tetraodontiformes were collected from Red Sea and River Nile respectively, in Egypt, then brought to the laboratory for the morphologically identification according to (Randall, 1982 and Bishai and Khalil, 1997). The muscles tissues were individually isolated and preserved in $-80^{\circ} \mathrm{C}$ until genomic DNA extraction.

\section{DNA Extraction:}

The genomic DNA from each puffer fish was extracted from the muscles tissues using the DNA extraction method of QIAamp DNA Mini kit (Qiagen, Hidden, Germany) depending on the manufacturer's instructions. 


\section{PCR Conditions:}

Polymerase chain reaction (PCR) amplification of genomic DNA was performed using forward and reverse primers of cyt-b (cytb F: 5'CCCTACTCGGACTTTGCCTG-3') and (cytb R: 5'-AATCGGGTGAGAGTTGCGTT$3^{\prime}$ ), also using forward and reverse primers of 16S rRNA (16S F: 5'GCCTGCCCTGTGACTATACG-3') and (16S R: 5'-TCGCCCCAACCAAAGACATT$\left.3^{\prime}\right)$. All primers were designed based on the (cyt-b and 16S rRNA) genes sequences described for the under study puffer fish Arothron hispidus using the National Center for Biotechnology Information (NCBI) database.

The PCR reactions were carried out with 10 pmoles of each primer, 100 ng of genomic DNA and $12.5 \mu \mathrm{L}$ PCR master mix in a final reaction volume of $25 \mu \mathrm{L}$. PCR reaction was carried out with, an initial denaturation for 2 minutes at $95{ }^{\circ} \mathrm{C}$, followed by 34 cycles for $30 \mathrm{~s}$ at $95^{\circ} \mathrm{C}$, annealing: for $30 \mathrm{~s}$ at $55^{\circ} \mathrm{C}$ and an extension at $72{ }^{\circ} \mathrm{C}$ for $10 \mathrm{~min}$. The PCR products were run on $1.3 \%$ agarose gel stained with ethidium bromide.

\section{The Sequencing of PCR Products:}

The PCR amplification and agarose gel electrophoresis resulted in a single band with each species; Arothron hispidus and Tetraodon lineatus of (337 and $367 \mathrm{bp}$., respectively) in cytochrome $b$ and of (186 and 237 bp., respectively) in 16S rRNA.

The sequenced regions of cytochrome b in Arothron hispidus and Tetraodon lineatus were submitted in the National Center for Biotechnology Information (GenBank/NCBI) under accession numbers (MN186251 and MN186252, respectively). Also the sequenced regions of 16S rRNA in Arothron hispidus and Tetraodon lineatus were submitted in the (GenBank/NCBI) under accession numbers (MN186287 and MN175976, respectively). Sequences of (cyt-b) were subjected to BLAST/N at the National Center for Biotechnology Information (NCBI) and revealed 13 related marine puffer fishes species in additional to two species as outgroup. Sequences of (16S rRNA) after BLAST/N at (NCBI) revealed 9 related marine puffer fishes and four related marine Boxfish species, Order Tetraodontiformes, in addition to three outgroup species (Table 1). The marine ecology of the selected fishes were detected according to (Randall, 1982) and the FishBase website.

Table1: The understudying puffer fishes and its related marine puffer fishes with outgroups from the GenBank/ NCBI based on (cyt-b) and (16S) genes sequences.

\begin{tabular}{|c|c|c|c|c|}
\hline \multicolumn{3}{|c|}{ (cyt b gene } & \multicolumn{2}{|c|}{$(16 S)$ genes } \\
\hline No. & Species & Accession umber & Species & Accession umber \\
\hline 1 & Tetraodon lineatus & MN186252 & Tetraodon lineatus & MN175976.1 \\
\hline 2 & Arothron hispidus & MN186251 & Arothron hispidus & MN186287.1 \\
\hline 3 & Arothron meleagris & JQ681861.1 & Arothron hispidus & AB742006.1 \\
\hline 4 & Arothron nigropunctatus & JQ681862.1 & Arothron reticularis & AB742012.1 \\
\hline 5 & Arothron diadematus & JQ681856.1 & Arothron diadematus & AB742004.1 \\
\hline 6 & Arothron firmamentum & GU057265.1 & Arothron firmamentum & AB742005.1 \\
\hline 7 & Arothron stellatus & JQ681863.1 & Arothron stellatus & AB742013.1 \\
\hline 8 & Arothron mappa & JQ681860.1 & Arothron mappa & AB742009.1 \\
\hline 9 & Arothron immaculatus & JQ681858.1 & Lagocephalus gloveri & KT718806.1 \\
\hline 10 & Arothron manilensis & JQ681859.1 & Lagocephalus lunaris & KT718807.1 \\
\hline 11 & Arothron hispidus & FJ434546.1 & Canthigaster valentini & AY679666.1 \\
\hline 12 & Canthigaster valentini & JQ681881.1 & Ostracion cubicus & DQ532926.1 \\
\hline 13 & Sphoeroides spengleri & JQ681909.1 & Lactophrys bicaudalis & AY679656.1 \\
\hline 14 & Sphoeroides testudineus & JQ681910.1 & Acanthostracion polygonius & КТ600989.1 \\
\hline 15 & Lagocephalus lunaris & MG817076.1 & Acanthostracion quadricornis & AY679659.1 \\
\hline \multirow{2}{*}{$\begin{array}{l}\text { Out } \\
\text { group }\end{array}$} & Lutjanus analis isolate 1 & $\begin{array}{l}\text { HQ162430.1 } \\
\text { HO1624311 }\end{array}$ & Cymolutes praetextatus & AY279696.1 \\
\hline & Lutjanus analis isolate 3 & HQ162432.1 & Cymolutes torquatus & AY279697.1 \\
\hline
\end{tabular}




\section{Sequence Alignments:}

Sequences of (cyt-b) and (16S rRNA) were aligned with homologous sequences of related species from the GenBank database. Phylogenetic analyses were performed with MEGA version 7.018 (Kumar et al., 2016), using Maximum likelihood (ML), Neighbour Joining (NJ) and Minimum Evolution (ME) methods of trees construction and using 1000 bootstrap iterations (Felsenstein, 1985). Sequence divergences were calculated using Kimura 2-parameter distances (Kimura, 1980) to provide a graphical representation of divergence between species.

\section{RESULTS}

We wanted to used the (mtDNA) sequences of cytochrome $b$ and 16S rRNA genes, to detect the best phylogenetic relationship between the species under study and its related marine puffer fishes. Our analysis inclusive Tetraodon lineatus species of puffer fish, represented species of Nile puffer fish and Arothron hispidus species of marine puffer fish.

\section{Sequence variation using cytochrome b: \\ Genetic distance:}

The nucleated sequence lengths using the cytochrome $\mathrm{b}$ gene in marine puffer fish Arothron hispidus and Nile puffer fish Tetraodon lineatus were (337 and $367 \mathrm{bp}$. respectively). The average content of $\mathrm{A}+\mathrm{T}$ contents and $\mathrm{C}+\mathrm{G}$ contents were similar in the two species (Table 2).

Table 2: Nucleotide frequencies and its average of cyt-b sequence in River Nile Tetraodon lineatus and marine Arothron hispidus.

\begin{tabular}{lcccccccc}
\hline \multirow{2}{*}{ Species } & Base pair & \multicolumn{9}{c}{ Nucleotide Number \% } & A+T & C+G \\
\cline { 3 - 6 } & length & A\% & T\% & C \% & G\% & Content (\%) & Content (\%) \\
\hline Arothron hispidus & 337 & 25.5 & 24.4 & 32 & 18.1 & 49.9 & 50.1 \\
Tetraodon lineatus & 367 & 25.1 & 24.8 & 32.7 & 17.4 & 49.9 & 50.1 \\
Average \% & - & 25.3 & 24.6 & 32.3 & 17.8 & 49.9 & 50.1 \\
\hline
\end{tabular}

Pairwise genetic distances among Nile puffer fish Tetraodon lineatus, marine puffer fishes and the out group, were estimated by MEGA version 7.018 (Kumar et al., 2016) using the $\mathrm{K}^{2} \mathrm{P}$ method with gamma correction. The P-distances among all fish species ranged from 0.000 to $0.060 \%$. Overall the distance value among all fish species was $0.156 \%$.

Among puffer fishes the highest P-distance (0.060) was found between Arothron mappa and Canthigaster valentini. While, the lowest value (0.000) was found between Tetraodon lineatus and understudied marine puffer fish Arothron hispidus, likewise between Arothron meleagris and Arothron nigropunctatus, also between Arothron immaculatus and Arothron manilensis (Table 3).

The low genetic distance values among Nile puffer fish Tetraodon lineatus and both of marine puffer fishes; the understudied Arothron hispidus (MN186251) and Arothron hispidus from the GenBank (FJ434546.1) (0.000 and 0.014, respectively), reflected the closely genetic linkage between Nile puffer fish Tetraodon lineatus and Arothron hispidus.

The results of (cyt-b) revealed that, the genetic distance value $(0.035)$ between Nile puffer fish Tetraodon lineatus and marine Canthigaster valentine was lower than the value (0.038) between Nile puffer fish Tetraodon lineatus and marine Arothron mappa. This expressed closely genetic relation among Canthigaster valentine and both of marine species of genus Arothron and Nile puffer species Tetraodon lineatus. 
Compared to all marine puffer fishes, Lagocephalus lunaris showed the greatest sequence divergence for Nile puffer fish Tetraodon lineatus.

Table 3: Pairwise distances based on (cyt-b) sequence using Kimura 2- parameter among River Nile Tetraodon lineatus and marine puffer fishes additional to the outgroup.

\begin{tabular}{|c|c|c|c|c|c|c|c|c|c|c|c|c|c|c|c|c|c|c|c|c|}
\hline & & & 2 & 3 & 4 & 5 & 6 & 7 & 8 & 9 & 10 & 11 & 12 & 13 & 14 & 15 & 16 & 17 & 18 & \\
\hline MN186252 Tetraodon lineatus & 1 & & 0.000 & 0.014 & 0.028 & & 9 & 29 & 29 & 30 & 30 & 38 & 35 & 56 & 40 & 40 & 43 & 45 & 45 & 1 \\
\hline & & & & & 28 & 8 & & & 29 & 30 & 30 & 38 & 35 & 56 & 40 & 40 & 143 & 045 & 45 & 2 \\
\hline 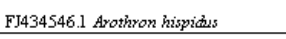 & & 30 & 030 & & 0.028 & 0.028 & 29 & 38 & 134 & 131 & 31 & 39 & 0.043 & 56 & 139 & 144 & 443 & 045 & 45 & 3 \\
\hline $\mathrm{JQ681}$ & 4 & 887 & 087 & 0.095 & & 0.000 & 0.010 & 224 & 022 & 027 & .027 & 0.028 & 0.042 & 0.049 & 050 & 242 & 045 & .047 & .047 & 4 \\
\hline JQ68 & 5 & 887 & 087 & 0.095 & 0.000 & & 0.010 & 024 & 022 & 027 & 027 & 0.028 & 0.042 & 0.049 & 0.050 & 042 & 045 & 1.047 & 0.047 & 5 \\
\hline JQ681856.1 Arothron diadematu. & 6 & 995 & 095 & .103 & 0.018 & 0.018 & & 0.026 & 020 & 227 & .027 & 0.027 & 0.044 & 342 & 051 & 039 & 043 & 1.045 & 0.045 & 6 \\
\hline JQ681863.1 Avothron stellatus & 7 & 0.095 & 0.095 & 0.138 & 0.071 & 0.071 & 0.079 & & 0.029 & 0.030 & 0.030 & 0.034 & 0.043 & 0.047 & 0.046 & .048 & .044 & 1.046 & 0.046 & 7 \\
\hline GU057265.1 Avothron firmamentron & 8 & 0.100 & .100 & 0.126 & 0.063 & 0.063 & 0.056 & 100 & & 0.026 & 0.026 & 0.022 & 0.047 & 0.040 & 0.051 & 040 & .043 & 1.045 & 0.045 & 8 \\
\hline 58.1 Arothron żrmaculatus & 9 & .102 & 102 & 0.110 & 0.093 & 0.093 & 0.086 & 0.102 & 092 & & 0.000 & 0.022 & 0.046 & 0.037 & 0.049 & .041 & 1039 & 0.041 & 0.041 & 9 \\
\hline $59.1 \mathrm{Az}$ & & 102 & 102 & 110 & 0.093 & 0.093 & 0.086 & 0.102 & 1.092 & .000 & & 022 & 0.046 & .037 & 0.049 & .041 & 1.039 & 1.041 & 0.041 & 10 \\
\hline 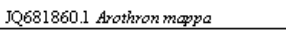 & & 0.138 & 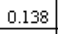 & 0.147 & 25 & 25 & & & 8 & 63 & 063 & & 60 & & 47 & 46 & 44 & 46 & 46 & 11 \\
\hline JQ68 & & 44 & 44 & 0.190 & 0.180 & 0.180 & 20 & 80 & 07 & 92 & 22 & 0.256 & & 8 & 150 & 44 & 148 & 050 & 50 & 12 \\
\hline MG81 & & 42 & 242 & 253 & 0.209 & 0.209 & 0.179 & 99 & 163 & 153 & 153 & 0.220 & 0.251 & & 0.057 & 043 & 0.042 & .042 & .042 & 0 \\
\hline JQ68 & & 170 & 170 & 170 & 0.220 & 0.220 & 0.230 & 99 & 227 & 211 & 211 & 0.209 & 0.211 & 0.261 & & 66 & .054 & 057 & \begin{tabular}{l|l}
0.057 \\
\end{tabular} & 14 \\
\hline JQ681910.1 Sphoero & 1 & 186 & 186 & 205 & 0.195 & 0.195 & 0.176 & 0.226 & 0.186 & 187 & 187 & 0.215 & 0.189 & 0.197 & 0.139 & & 0.035 & 0.037 & 0.037 & 15 \\
\hline $\mathrm{HQ162430.1} \mathrm{Lut}$ & 1 & 0.203 & 203 & 212 & 0.212 & 0.212 & 0.203 & 212 & 203 & 1.175 & .175 & 0.203 & 0.215 & 0.185 & 0.249 & 151 & & 0.006 & 0.006 & 16 \\
\hline $31.1 \mathrm{Lu}$ & 17 & 0.212 & 212 & 0.222 & 0.222 & 0.222 & 0.212 & 222 & 212 & 184 & 184 & 0.212 & 0.226 & 0.185 & 261 & 160 & 006 & & 0.000 & 17 \\
\hline HQ162432.1 Lutianus analis isolate_ 3 & 18 & 0.212 & 0.212 & 222 & 0.222 & 0.222 & 0.212 & 0.222 & 0.212 & 0.184 & 0.184 & 0.212 & 0.226 & 0.185 & 0.261 & .160 & .006 & 000 & & 8 \\
\hline & & 1 & 2 & 3 & 4 & & & 7 & 8 & 9 & 10 & & 11 & 15 & 17 & & & & 18 & \\
\hline
\end{tabular}

The Pairwise genetic distances among understudied Arothron hispidus and other species of genus Arothron ranged from 0.014 to 0.038 , and among other genera from 0.035 to 0.056. Based on (cyt-b) gene results, Arothron meleagris and Arothron nigropunctatus were closely related to Arothron hispidus where the genetic distance value was (0.028), but Arothron mappa was the highest genetic distance to Arothron hispidus (0.038) comparing to other species of genus Arothron. The results illustrated that, Lagocephalus lunaris was the highest genetic distance (0.056) to Arothron hispidus among all puffer fish species.

\section{Phylogenetic inference:}

To carry out the phylogenetic analysis, Nile puffer fish Tetraodon lineatus and marine puffer fish Arothron hispidus were submitted to analysis together with 13 of other marine puffer fishes sequences from GenBank/NCBI, representing four genera of family Tetraodontidae (Genus Arothron includes nine species, genus Sphoeroides contains two species and one species of both genera; Canthigaster and Lagocephalus), in addition to 3 species as outgroup (Lutjanus, Family Lutjanidae, Order Perciformes) (Table 1).

To confirm the phylogenetic relations among puffer fishes we used three phylogenetic methods; Maximum likelihood (ML), Neighbour Joining (NJ) and Minimum Evolution (ME) based on cytochrome $b$ gene. All methods showed the same relations among puffer fishes with some differents in support values, and revealed 5 main features: (1) species of the outgroup formed a separate cluster, (2) Lagocephalus lunaris formed a separate cluster from the rest of puffer fishes, (3) all species under genus Arothron found in one clad and formed some sister clads with each others, (4) all trees illustrated that, the under study Nile puffer fishes Tetraodon lineatus was closely related to genus Arothron than other marine puffer fishes genera, (5) The under study puffer fishes Nile Tetraodon lineatus and marine puffer fish Arothron hispidus (MN186251 and FJ434546.1) were found as a sister clad, which indicated the related linkage between them (Figs. 1-3). 


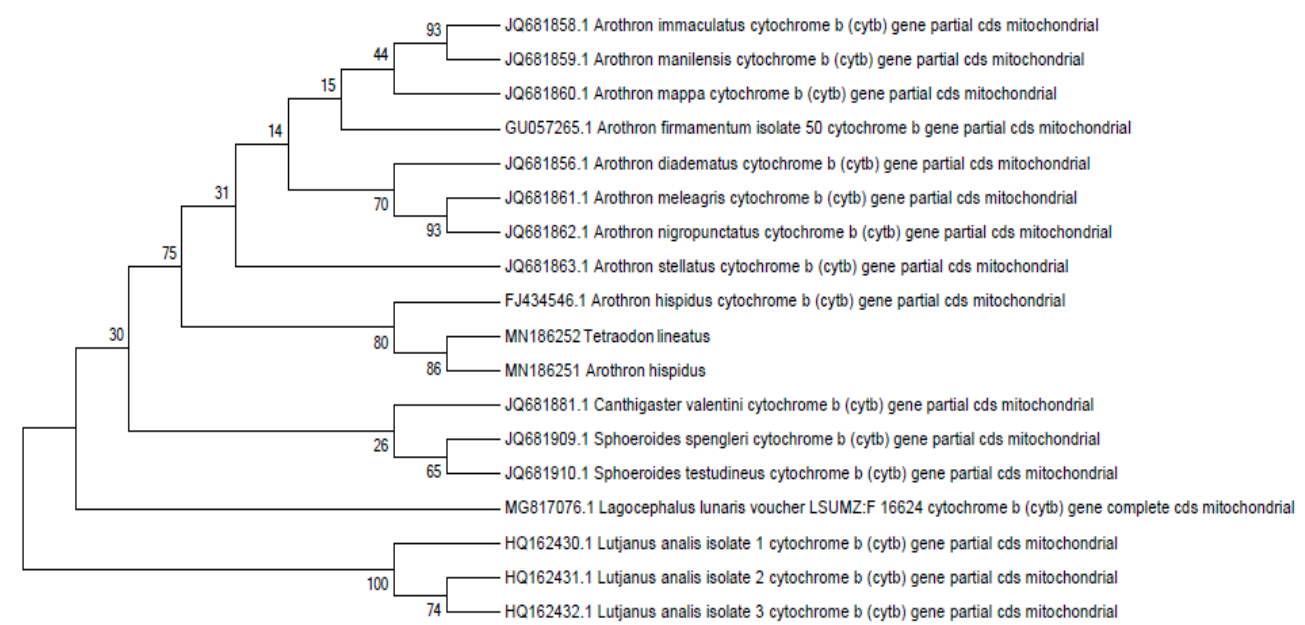

Fig. 1: Phylogenetic tree using the Maximum Likelihood method among Nile puffer fish Tetraodon lineatus and marine puffer fishes based on (cyt-b) including the outgroup.

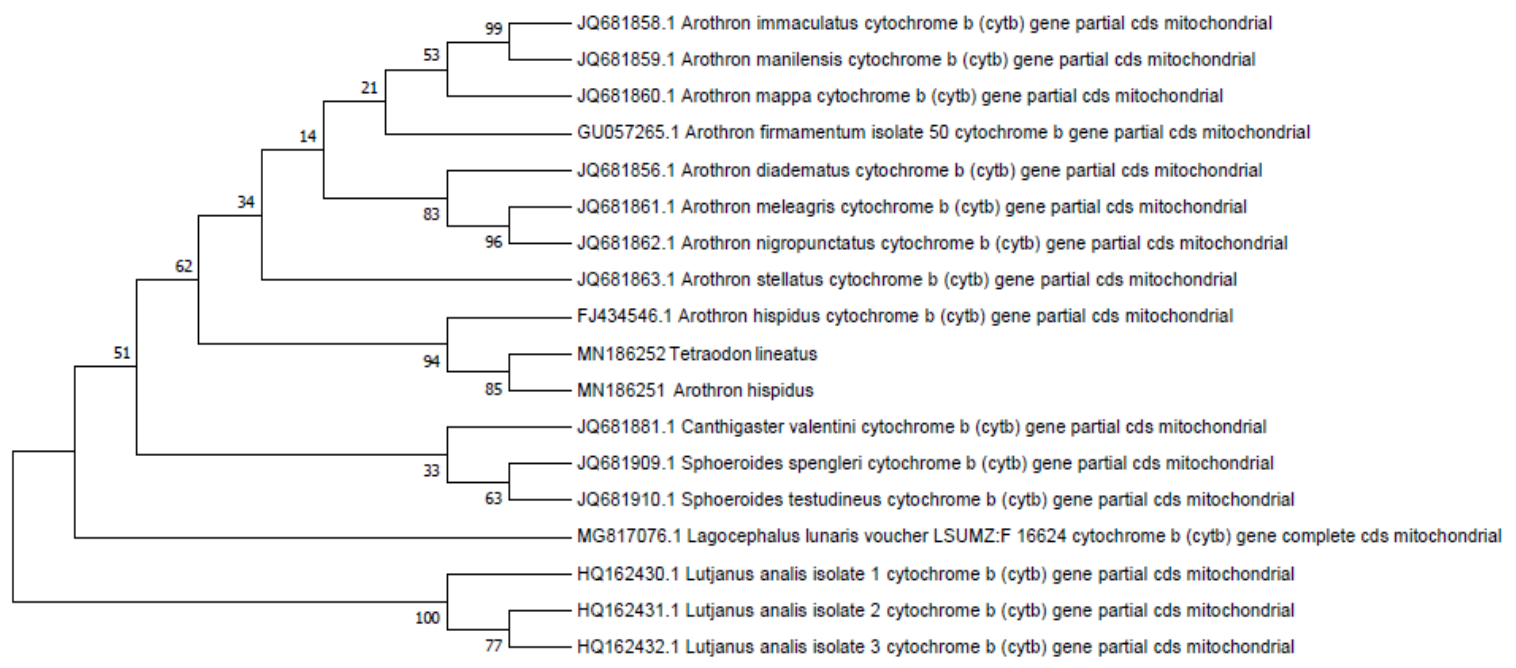

Fig. 2: Phylogenetic tree using the Neighbor Joining method among Nile puffer fish Tetraodon lineatus and marine puffer fishes based on (cyt-b) including the outgroup.

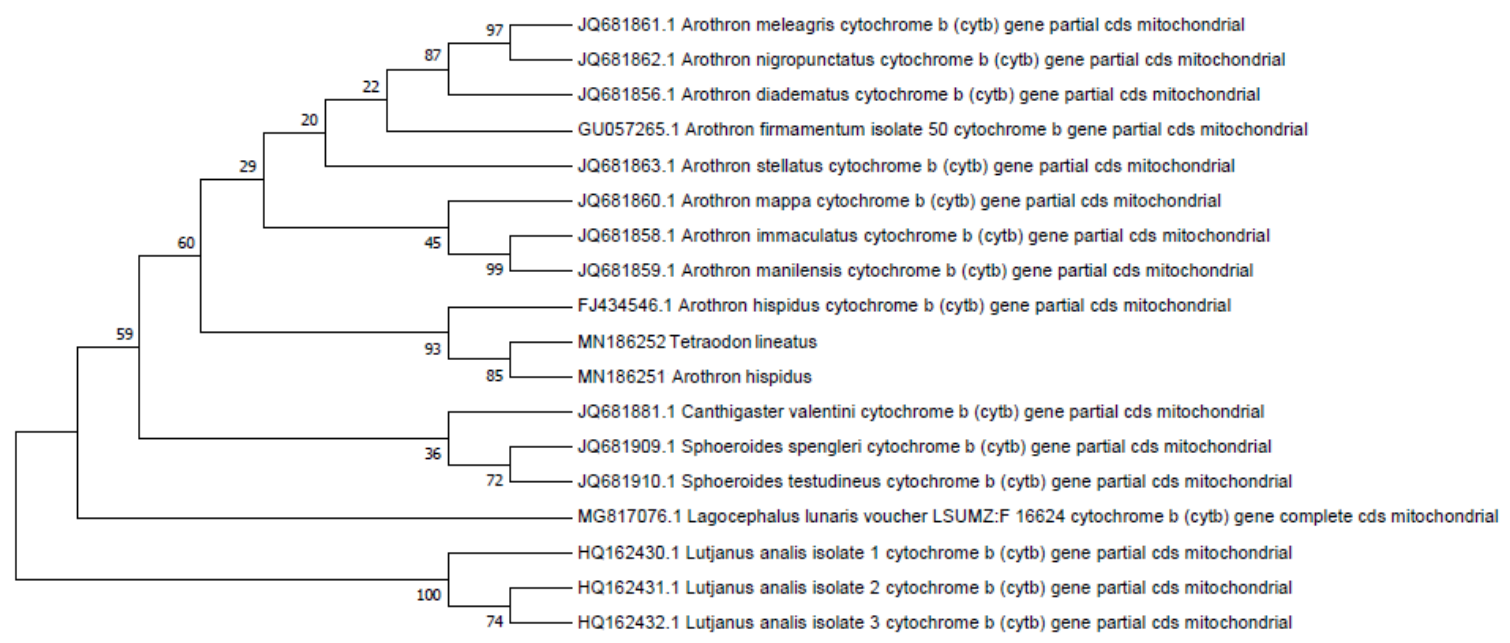

Fig. 3: Phylogenetic tree using the Minimum Evolution method among Nile puffer fish Tetraodon lineatus and marine puffer fishes based on (cyt-b) including the outgroup. 


\section{Sequence variation using $16 S$ : Genetic distance:}

In additional to Nile puffer fish Tetraodon lineatus has longer DNA sequencing than marine puffer fish Arothron hispidus, the results also illustrated that, $\mathrm{C}+\mathrm{G}$ contents of Tetraodon lineatus (47.3) were higher than that of Arothron hispidus (40.3), but A+T contents of Arothron hispidus were higher than that of Tetraodon lineatus (Table 4).

Table 4: Nucleotide frequencies and its average of $16 \mathrm{~S}$ sequence in River Nile Tetraodon lineatus and marine Arothron hispidus.

\begin{tabular}{lccccccc}
\hline \multicolumn{1}{c}{ Species } & $\begin{array}{c}\text { Base pair } \\
\text { length }\end{array}$ & \multicolumn{4}{c}{ Nucleotide Number \% } & \multirow{2}{A}{$+\mathrm{T}$} & $\mathrm{G}+\mathrm{C}$ \\
\cline { 3 - 6 } & & $\mathrm{A} \%$ & $\mathrm{~T} \%$ & $\mathrm{C} \%$ & $\mathrm{G} \%$ & & \\
\hline Arothron hispidus & 186 & 33.3 & 26.4 & 17.2 & 23.1 & 59.7 & 40.3 \\
Tetraodon lineatus & 237 & 32 & 20.7 & 23.2 & 24.1 & 52.7 & 47.3 \\
Average \% & - & 32.7 & 23.5 & 20.2 & 23.6 & 56.2 & 43.8 \\
\hline
\end{tabular}

The percentage of genetic distance values among puffer fishes species ranged from 0.000 to 0.105 , while among all species ranged from 0.00 to $0.149 \%$. Overall the distance value among all fish species was $0.161 \%$ (Table 5).

The genetic distance values among Nile puffer fish Tetraodon lineatus and marine puffer fish species of genus Arothron ranged from (0.016 to 0.083). While the values of genetic distance among Nile puffer fish Tetraodon lineatus and marine species; Canthigaster valentine, Lagocephalus lunaris, Lagocephalus gloveri, Acanthostracion polygonius, Acanthostracion quadricornis, Ostracion cubicus and Lactophrys bicaudalis ranged from (0.030 to 0.043).

Table 5: Pairwise distances based on (16S) sequence using Kimura 2-parameter among River Nile Tetraodon lineatus and marine puffer fishes additional to the outgroup.

\begin{tabular}{|c|c|c|c|c|c|c|c|c|c|c|c|c|c|c|c|c|c|c|c|}
\hline & & 1 & 2 & 3 & 4 & 5 & 6 & 7 & 8 & 9 & 10 & 11 & 12 & 13 & 14 & 15 & 16 & 17 & \\
\hline MN175976.1 Tetraxadon lineatus & $\mathbf{l}$ & & 0.083 & 0.016 & 0.022 & 0.028 & 0.027 & 0.027 & 0.031 & 0.030 & 0.039 & 0.039 & 0.041 & 0.043 & 0.041 & 0.043 & 0.042 & 0.043 & 1 \\
\hline MN186287.1 Arationisispiass & 2 & 0.346 & & 0.062 & 0.076 & 0.085 & 0.080 & 0.081 & 0.081 & 0.100 & 0.105 & 0.105 & 0.142 & 0.149 & 0.142 & 0.130 & 0.110 & 0.111 & 2 \\
\hline AB742006.1 Arotion isispias & 3 & 0.041 & 0.268 & & 0.011 & 0.018 & 0.017 & 0.017 & 0.020 & 0.023 & 0.027 & 0.027 & 0.033 & 0.034 & 0.033 & 0.034 & 0.035 & 0.033 & 3 \\
\hline 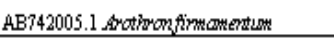 & 4 & 0.068 & 0.321 & 0.023 & & 0.012 & 0.013 & 0.010 & 0.017 & 0.024 & 0.024 & 0.024 & 0.033 & 0.037 & 0.032 & 0.033 & 0.040 & 0.032 & 4 \\
\hline AB742013.1 Arotion stellatus & 5 & 0.097 & 0.351 & 0.048 & 0.023 & & 0.017 & 0.017 & 0.018 & 0.027 & 0.023 & 0.023 & $0.03 ?$ & 0.040 & 0.038 & 0.035 & 0.041 & 0.032 & 5 \\
\hline AB742009.1 Aration & 6 & 0.089 & 0.336 & 0.041 & 0.029 & 0.041 & & 0.012 & 0.016 & 0.022 & 0.033 & 0.033 & 0.042 & 0.044 & 0.041 & 0.039 & 0.048 & 0.039 & 6 \\
\hline AB742004.1 Arotion di dorimatus & 7 & 0.089 & 0.336 & 0.041 & 0.017 & 0.041 & 0.023 & & 0.016 & 0.022 & 0.029 & 0.029 & 0.035 & 0.040 & $0.03 ?$ & 0.032 & 0.042 & 0.033 & 7 \\
\hline AB742012.1 Arotion reticularis & 8 & 0.112 & 0.346 & 0.061 & 0.047 & 0.047 & 0.041 & 0.041 & & 0.026 & 0.033 & 0.033 & 0.040 & 0.042 & 0.042 & 0.038 & 0.042 & 0.034 & 8 \\
\hline AY679666.1 Coutingater valenting & 9 & 0.105 & 0.400 & 0.068 & 0.068 & 0.083 & 0.061 & 0.061 & 0.082 & & 0.030 & 0.030 & 0.035 & 0.040 & 0.036 & 0.037 & 0.041 & 0.038 & 9 \\
\hline onsis & 10 & 0.153 & 0.423 & 0.096 & 0.081 & 0.074 & 0.120 & 0.104 & 0.127 & 0.104 & & 0.000 & 0.042 & 0.045 & 0.038 & 0.040 & 0.044 & 0.046 & 10 \\
\hline KT718806.1 Lagocephalus giover & 11 & 0.153 & 0.423 & 0.096 & 0.081 & 0.074 & 0.120 & 0.104 & 0.127 & 0.104 & 0.000 & & 0.042 & 0.045 & 0.038 & 0.040 & 0.044 & 0.046 & 11 \\
\hline KT600989.1 Acouthastracion polygonius & 12 & 0.174 & 0.559 & 0.132 & 0.132 & 0.157 & 0.176 & 0.140 & 0.174 & 0.149 & 0.185 & 0.185 & & 0.016 & 0.024 & 0.018 & 0.046 & 0.039 & 12 \\
\hline AY679659.1 Acauthastracion quadriconds & 13 & 0.176 & 0.567 & 0.133 & 0.150 & 0.168 & 0.177 & 0.159 & 0.176 & 0.168 & 0.194 & 0.194 & 0.041 & & 0.028 & 0.016 & 0.042 & 0.039 & 13 \\
\hline Q532926.1 Ostracion custicus & 14 & 0.173 & 0.574 & 0.131 & 0.131 & 0.165 & 0.174 & 0.156 & 0.182 & 0.147 & 0.165 & 0.165 & 0.093 & 0.108 & & 0.025 & 0.051 & 0.050 & 14 \\
\hline 56.1 Lato & 15 & 0.174 & 0.515 & 0.132 & 0.132 & 0.140 & 0.157 & 0.124 & 0.156 & 0.149 & 0.166 & 0.166 & 0.048 & 0.041 & 0.093 & & 0.040 & 0.036 & 15 \\
\hline AY279696.1 Cynolutes prostextatus & 16 & 0.178 & 0.483 & 0.152 & 0.179 & 0.188 & 0.217 & 0.188 & 0.196 & 0.179 & 0.197 & 0.197 & 0.197 & 0.185 & 0.236 & 0.168 & & 0.021 & 16 \\
\hline \multirow[t]{2}{*}{ AY279697.1 Cynolutes torquatus } & 17 & 0.180 & 0.475 & 0.137 & 0.129 & 0.129 & 0.163 & 0.137 & 0.145 & 0.163 & 0.207 & 0.207 & 0.168 & 0.160 & 0.229 & 0.141 & 0.060 & & 17 \\
\hline & & 1 & 2 & 3 & 4 & 5 & 6 & 7 & 8 & 9 & 10 & 11 & 12 & 13 & 14 & 15 & 16 & 17 & \\
\hline
\end{tabular}

The genetic distance value (0.030) between Nile puffer fish Tetraodon lineatus and marine Canthigaster valentine was little than the value $(0.031)$ between Nile puffer fish Tetraodon lineatus and marine Arothron reticularis. That indicated the closely genetic relation among Canthigaster valentine and marine species of genus 
Arothron in one side and Nile puffer fish Tetraodon lineatus in the other side. The results of (16S) sequencing revealed that, the pairwise genetic distances among understudied Arothron hispidus and other species of genus Arothron ranged from 0.062 to 0.085 , and among other genera ranged from 0.100 to 0.149 (Table 5).

The four species of Boxfishes, Family Ostraciidae, Order Tetraodontiformes were genetically distanced from the understudied species compared to species of family Tetraodontidae.

In general, the Nile puffer fish Tetraodon lineatus was distantly related to marine puffer fishes of genera Arothron and Canthigaster more than the rest of marine genera; Lagocephalus, Acanthostracion, Ostracion and Lactophrys. Among all samples Arothron hispidus (AB742006.1) and Arothron firmamentum (AB742005.1) were related to the Nile puffer fish Tetraodon lineatus, where the genetic distance values were 0.016 and 0.022 , respectively.

\section{Phylogenetic inference:}

To carry out the phylogenetic analysis using (16S) sequencing, Nile puffer fish Tetraodon lineatus and marine puffer fish Arothron hispidus were submitted to analysis together with 13 of other marine fishes sequences from GenBank/NCBI, representing nine species of Family Tetraodontidae, Order Tetraodontiformes, found in three genera (Arothron includes six species, Lagocephalus contains two species and one species of genus Canthigaster). Also, the blastn results of GenBank/NCBI showed similarity with four species of Boxfishes, Family Ostraciidae, Order Tetraodontiformes, which were (Ostracion cubicus, Acanthostracion polygonius, Acanthostracion quadricornis and Lactophrys bicaudalis). In addition to the outgroup sequences (Cymolutes, family Labridae, Order Perciformes) (Table 1).

For more illustrative phylogenetic relations, we used more than one phylogenetic method; Maximum likelihood, Neighbour Joining and Minimum Evolution based on $16 \mathrm{~S}$ gene. The methods revealed 3 main features: (1) species of the outgroup formed a separate cluster, (2) species of Boxfishes formed a separate cluster from the rest fishes, (3) the results illustrated that, the under study marine puffer fish Arothron hispidus found in a sister clad with Arothron hispidus from GenBank, and the Nile puffer fish Tetraodon lineatus was very related to this clad, which indicated the related linkage between Tetraodon lineatus and genus Arothron, specially species Arothron hispidus (Figs. 4-6).

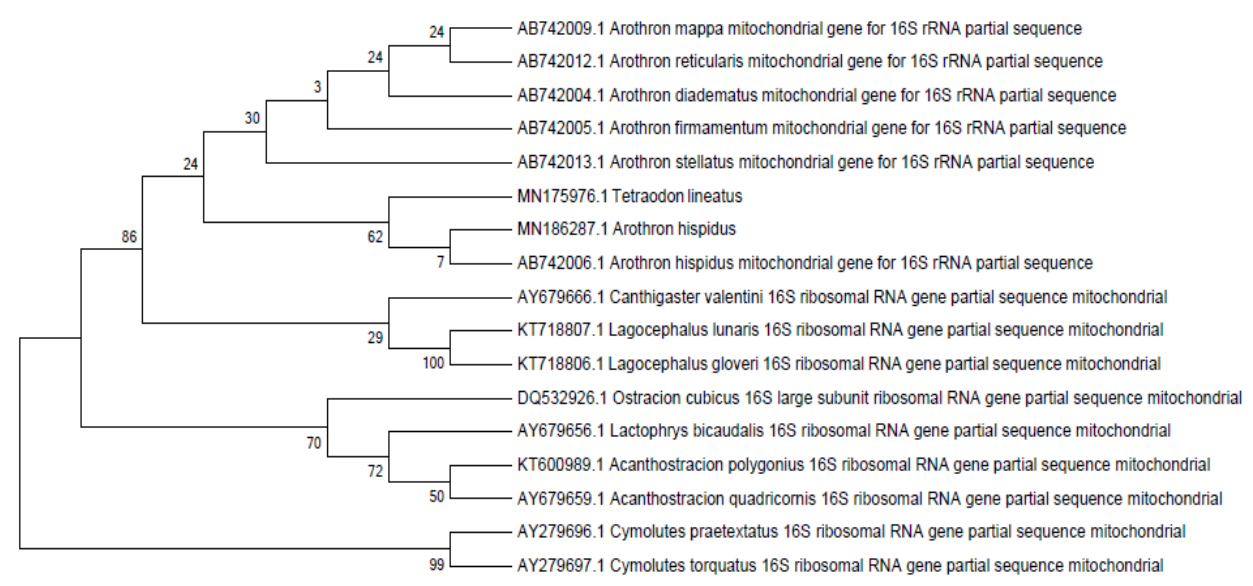

Fig. 4. Phylogenetic tree using the Maximum Likelihood method among Nile puffer fish Tetraodon lineatus and marine puffer fishes based on (16S) including the outgroup species. 


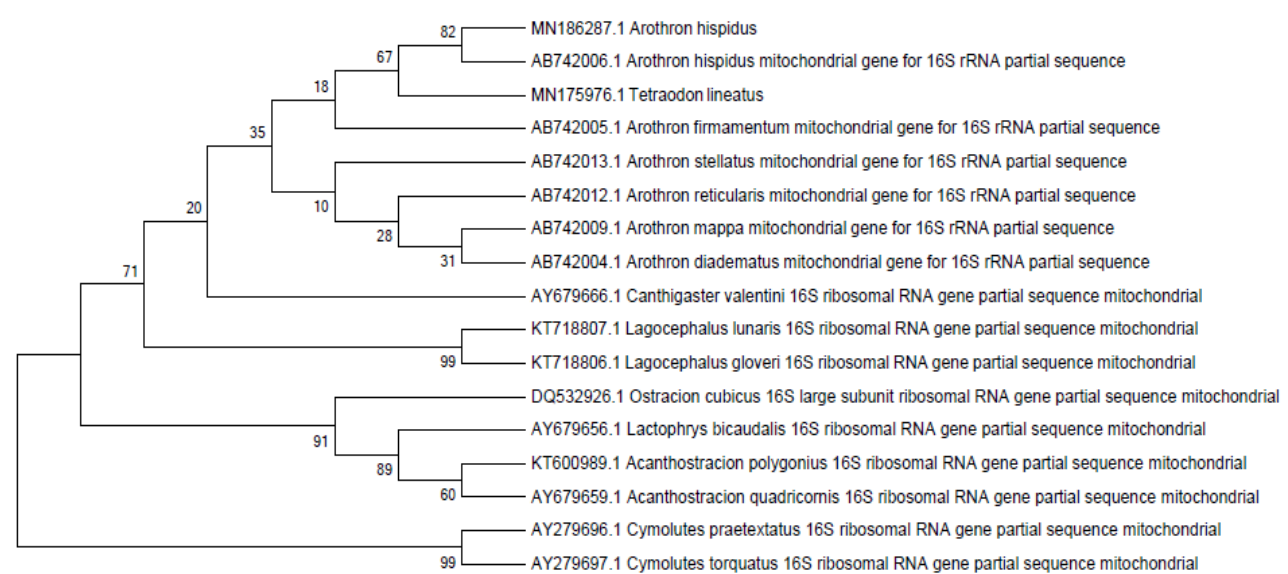

Fig. 5: Phylogenetic tree using the Neighbor Joining method among Nile puffer fish Tetraodon lineatus and marine puffer fishes based on (16S) including the outgroup species.

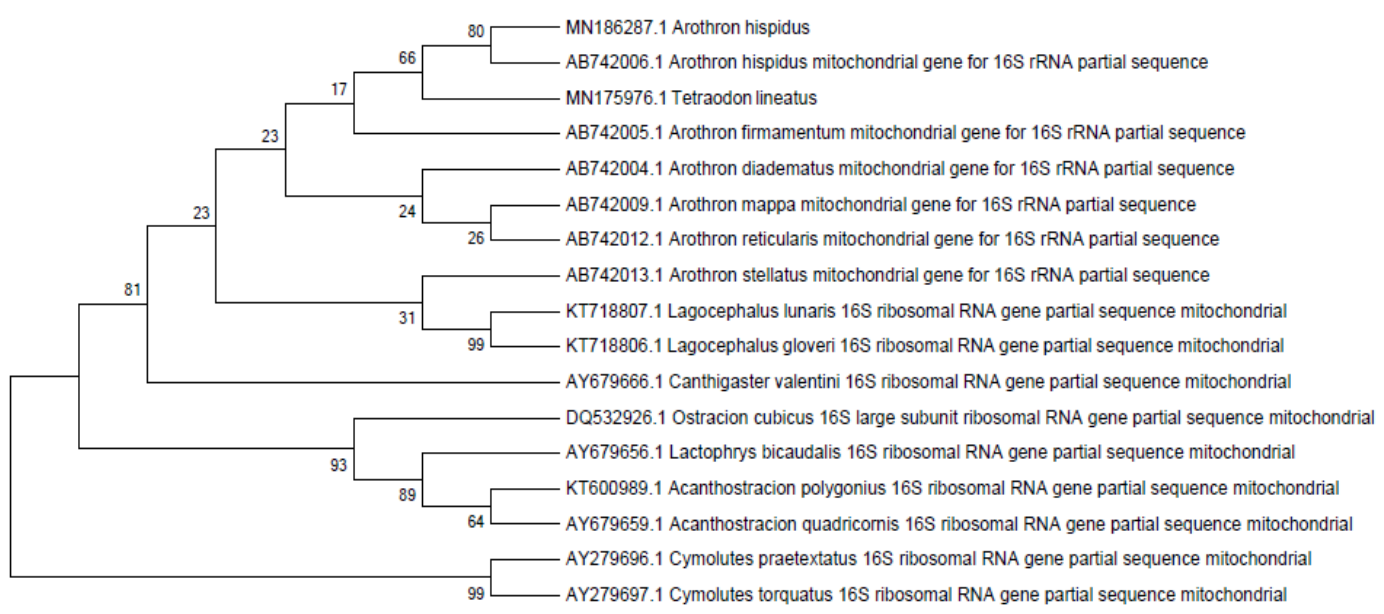

Fig. 6. Phylogenetic tree using the Minimum Evolution method among Nile puffer fish Tetraodon lineatus and marine puffer fishes based on (16S) including the outgroup species.

\section{DISCUSSION}

The study of nucleotide variations among fishes is the main principle for exploring biodiversity via molecular markers (Noikotr et al., 2013; Saad and Abd El-Sadek, 2017 and Saad, 2019). Puffer fishes are suitable group to study the genome size evolution, specially, family Tetraodontidae which has a haploid genome size of 400 million bp. (Hinegardner and Rosen, 1972 and Neafsey and Palumbi, 2003).

In Egypt, Tetraodon lineatus is the single freshwater puffer fish species (Geba et al., 2016). Our phylogenetic reconstruction was carried out to provide a comprehensive analysis of the evolutionary relationships among Nile Tetraodon lineatus and marine puffer fishes, in additional to the phylogenetic linkage among Egyptian Red Sea Arothron hispidus and its related marine puffer fishes species from GenBank/NCBI using cytochrome $b$ and $16 \mathrm{~S}$ genes.

The cytochrome $b$ characterized by its sequence variability which makes it very useful in the phylogenetic relationships of species within genera and families (Castresana, 2001). So we used the cytochrome $b$ gene to give a general view about the molecular linkages of the Nile puffer fish Tetraodon lineatus and other marine puffer fishes specially Arothron hispidus using the available data on GenBank/NCBI.

Kaleshkumar et al. (2015) reported that, closely related species have the lowest genetic distance, while the highest genetic distance refers to highly diverged case. Based on Sequence variation using cytochrome b, the understudied Arothron hispidus 
was closely related to Arothron stellatus (0.029) than Arothron immaculatus (0.30) this was agree with the results of (Kaleshkumar et al., 2015), who found Arothron hispidus was closely related to Arothron stellatus than Arothron immaculatus based on (mt COI). The same author showed that, Arothron hispidus was closely related to Arothron stellatus than Arothron nigropunctatus based on (mt COI), but our results based on (cyt-b) revealed lower genetic distance between Arothron hispidus and Arothron nigropunctatus than Arothron hispidus and Arothron stellatus.

The studies of (Cantatore et al., 1994; Almodovar et al., 2000; Duokakis, 2000 and Çiftci et al., 2013) on the cytochrome b gene illustrated that, the cyt-b gene tend to be rich in $\mathrm{C}, \mathrm{A}$, and $\mathrm{T}$ nucleotide ratios, but low in $\mathrm{G}$ content, this was agree with our results, where the nucleotide ratios of $\mathrm{C}, \mathrm{A}$ and $\mathrm{T}$ respectively was more than $\mathrm{G}$ ratios (Table 2).

In many fishes studies, 16S rRNA gene has been the system of choice for barcoding and identification of fishes because of it is easier to amplify and sequence (Miglietta et al., 2009; Moura et al., 2011; Rosas, et al., 2018 and Saad, 2019). There for, we used the (16S) sequencing to reveal the molecular phylogenetics relationships of Nile puffer fish Tetraodon lineatus and Arothron hispidus to marine puffer fishes using the available data on GenBank/NCBI.

The results of $16 \mathrm{~S}$ rRNA gene sequence illustrated that, A+T contents of both Tetraodon lineatus and Arothron hispidus were higher than $\mathrm{C}+\mathrm{G}$ contents (Table 4), this was in corroboration with (Lakra et al., 2009 and Singh et al., 2015) who found high A+T contents in their study on fishes using 16S rRNA.

The high genetic distance values of 16S rRNA gene among Arothron hispidus and other species of puffer fishes (0.062 to 0.149) indicating its efficiency to reveal the phylogenetic relationships among the puffer fishes, this was in agreement with (Vinson et al., 2004, Chakraborty et al., 2006 a and b and Singh et al., 2015) who reported high nucleotide divergence among their under studied fishes using 16S gene, indicating the usefulness of this gene sequence for accurate identification of species.

The results indicated that the 16S rRNA system was efficient (Quraishia et al., 2015) in detecting genetic variations among these fishes. The blastn results of (16S) sequencing in the GenBank/NCBI showed similarity with four species of Boxfishes, family Ostraciidae, Order Tetraodontiformes which were not appeared with (cyt-b). We suggested that, this may be due to the highly conserved of (16S rRNA) gene, which was in agreement with (Singh et al., 2015).

The results of (16S rRNA) gene were in similarity with that of (cyt-b), where both genes revealed that, Nile puffer fish Tetraodon lineatus was closely related to genus Arothron than other marine puffer fishes genera. Also, low genetic distance value among Canthigaster valentine and both of Nile puffer fish Tetraodon lineatus and species of genus Arothron reflects the genetic relationships among them. These similarity results between (16S rRNA) and (cyt-b) genes indicate to high efficiency of both genes to investigate the genetic linkages among various species and genera as were observed in many studies like (Kartavtsev et al., 2007; Teletchea, 2009; Singh et al., 2015 and Saad, 2019).

\section{CONCLUSION}

Tetraodon lineatus is the single freshwater puffer fish in Egypt, so our study was performed to examine the phylogenetic relationships among the River Nile Tetraodon lineatus and the Red Sea Arothron hispidus to other marine puffer fishes using the available data on GenBank/NCBI, based on Mitochondrial DNA (mtDNA) 
sequences of cytochrome $b$ and 16S rRNA genes. The results of both (16S) and (cyt-b) genes were very similar to each others and illustrated closely genetic linkage among Nile puffer fishes Tetraodon lineatus and marine species of genus Arothron as well as Canthigaster valentine species. These similarity results of (16S rRNA) and (cyt-b) genes proved the usefulness of them for phylogenetic analysis of puffer fishes.

\section{REFERENCES}

Almodovar, A.; Machordom, A. and Suárez, J. (2000). Preliminary Results from Characterization of The Iberian Peninsula Sturgeon Based on Analysis of the mtDNA Cytochrome b. Boletin-Instituto Espanol de Oceanografia, 16: 17-27.

Bajpai, N. and Tewari, R.R. (2010). Mitochondrial DNA sequence-based phylogenetic relationship among flesh flies of the genus Sarcophaga (Sarcophagidae: Diptera). Journal of Genetics, 89 (1): 51-54.

Bishai, H.M. and Khalil, M.T. (1997). Freshwater fishes of Egypt. Department of Nature Protection, Publication of National Biodiversity Unit, No. 9, Egyptian Environmental Affairs Agency, Egypt, 229 pp.

Brainerd, E.L.; Slutz, S.S.; Hall, E.K. and Phillis, R.W. (2001). Patterns of genome size evolution in tetraodontiform fishes. Evolution, 55 (11): 2363-2368.

Brenner, S.; Elgar, G.; Sandford, R.; Macrae, A.; Venkatesh, B. and Aparicio, S. (1993). Characterization of the pufferfish (fugu) genome as a compact model vertebrate genome. Nature, 366 (2): 265-268.

Callejas, C. and Ochando, M.D. (2000). Recent radiation of Iberian barbel fish (Teleostei, Cyprinidae) inferred from cytochrome b genes. Journal of Heredity, 91 (4): 283-288.

Cantatore, P.; Roberti, M.; Pesole, G.; Ludovico, A.; Milella, F.; Gadaleta M.N. and Saccone, C. (1994). Evolutionary Analysis of Cytochrome b Sequences in Some Perciformes: Evidence for a Slower Rate of Evolution than in Mammals. Journal of Molecular Evolution, 39 (6): 589-597.

Castresana, J. (2001). Cytochrome b Phylogeny and the Taxonomy of Great Apes and Mammals. Molecular Biology and Evolution, 18 (4): 465-471.

Chakraborty, A.; Aranishi, F. and Iwatsuki, Y. (2006a). Genetic differences among three species of the genus Trichiurus (Perciformes: Trichiuridae) based on mitochondrial DNA analysis. Ichthyological Research, 53 (1): 93-96.

Chakraborty, A.; Venugopal, M.N.; Hidaka, K. and Iwatsuki Y. (2006b). Genetic differentiation between two color morphs of Gerres erythrourus (Perciformes: Gerreidae) from the Indo-Pacific region. Ichthyological Research, 53 (2): 185188.

Çiftci, Y.; Eroğlu, O. and Firidin, Ş. (2013). Mitochondrial Cytochrome b Sequence Variation in Three Sturgeon Species (A. stellatus Pallas, 1771, A. gueldenstaedtii Brandt, 1833, H. huso Linnaeus, 1758) from the Black Sea Coasts of Turkey. Turkish Journal of Fisheries and Aquatic Sciences, 13 (2): 291-303.

Doukakis, P. (2000). Systematics and Conservation Genetics of Sturgeons (Order: Acipenseriformes), $\mathrm{PhD}$ Thesis, Yale University.

Elgar, G.; Sandford, R.; Aparico, S.; Macrae, A.; Venkatesh, B. and Brenner, S. (1996). Small is beautiful: comparative genomics with the pufferfish (Fugu rubripes). Trends in Genetics, 12 (4): 145-150.

Faddagh, M.S.; Husain, N.A. and Al-Badran, A.I. (2012). Usage Mitochondrial 16S rRNA Gene as Molecular Marker in Taxonomy of Cyprinin Fish Species 
(Cyprinidae: Teleostei). Journal of King Abdulaziz University, Marine Science, 23 (1): 39-49.

Felsenstein, J. (1985). Confidence limits on phylogenies: An approach using the bootstrap. Evolution, 39 (4): 783-791.

Geba, K.M.; Mahdy, A.A.; Eissa, A.S.A. and Osman, A.G.M. (2016). Analysis of Population Genetics of the Endangered Nile Pufferfish Tetraodon lineatus (Linnaeus, 1758) in the Upper Egyptian River Nile. International Journal of Ecotoxicology and Ecobiology. 1 (2): 60-66.

Hinegardner, R. (1968). Evolution of cellular DNA content in teleost fishes. The American Naturalist, 102 (928): 517-523.

Hinegardner, R. and Rosen, D.E. (1972). Cellular DNA content and the evolution of teleostean fishes. The American Naturalist, 106 (951): 621-644.

Irwin, D.M.; Kocher, T.D. and Wilson A.C. (1991). Evolution of the cytochrome b gene of mammals. Journal of Molecular Evolution, 32 (2): 128-144

Jaillon, O.; Aury, J.M.; Brunet, F.; Petit, J.-L.; Stange-Thomann, N. and Mauceli, E., et al. (2004). Genome duplication in the teleost fish Tetraodon nigroviridis reveals the early vertebrate proto-karyotype. Nature, 431 (7011): 946-957.

Johns, G.C. and Avise J.C. (1998). A comparative summary of genetic distances in the vertebrates from the mitochondrial cytochrome $b$ gene. Molecular Biology and Evolution, 15 (11): 1481-1490.

Kai, W.; Kikuchi, K.; Fujita, M.; Suetake, H.; Fujiwara, A.; Yoshiura, Y.; Ototake, M.; Venkatesh, B.; Miyaki, V. and Suzuki, Y. (2003). A genetic linkage map for the tiger pufferfish, Takifugu rubripes. Genetics, 171 (1): 227-238.

Kaleshkumar, K.; Rajaram, R.; Vinothkumar, S.; Ramalingam, V. and Meetei, K.B. (2015). DNA barcoding of selected species of pufferfishes (Order: Tetraodontiformes) of Puducherry coastal waters along south-east coast of India. Indian Journal of Fisheries, 62 (2): 98-103.

Karaiskou, N.; Apostolidis, A.P.; Triantafyllidis, A.; Kouvatsi, A. and Triantaphyllidis, C. (2003). Genetic identification and phylogeny of three species of the genus Trachurus based on mitochondrial DNA analysis. Marine Biotechnology, 5 (5): 493-504.

Kartavtsev, Y.P.; Jung, S.O.; Lee, Y.M.; Byeon, H.K. and Lee, J.S. (2007). Complete mitochondrial genome of the bullhead torrent catfish, Liobagrus obesus (Siluriformes, Amblycipididae): Genome description and phylogenetic considerations inferred from the Cyt $b$ and 16S rRNA genes. Gene, 396 (1): 1327.

Kimura, M. (1980). A simple method for estimating evolutionary rates of base substitutions through comparative studies of nucleotide sequences. Journal of Molecular Evolution, 16 (2): 111-120.

Kochzius, M. (2009). Trends in fishery genetics. In: Beamish, R.J. and Rothschild, B.J. (Eds), The future of fisheries science in North America. Dordrecht, The Netherlands: Fish and Fisheries Series. Springer, pp 453-493.

Koop, B.F. and Nadeau, J.H. (1996). Pufferfish and new paradigm for comparative genome analysis. Proceedings of the National Academy of Sciences, 93 (4): 1363-1365.

Kumar, S.; Stecher, G. and Tamura, K. (2016). MEGA7: Molecular Evolutionary Genetics Analysis Version 7.0 for Bigger Datasets. Molecular Biology and Evolution, 33 (7): 1870-1874.

Lakra, W.S.; Goswami, M. and Gopalakrishnan, A. (2009). Molecular identification and phylogenetic relationships of seven Indian Sciaenids (Pisces: Perciformes, 
Sciaenidae) based on 16S rRNA and cytochrome $\mathrm{c}$ oxidase subunit I mitochondrial genes. Molecular Biology Reports, 36 (5), 831-839.

McClane, A.J. (1977). The Encyclopedia of Fish Cookery. Holt, Rinehart and Winston, $511 \mathrm{pp}$.

McVeigh, H.P. and Davidson, W.S. (1991). A Salmon id phylogeny inferred from mitochondrial cytochrome b gene sequences. Journal of Fish Biology, 39 (A): 277-282.

Miglietta, M.P.; Schuchert, P. and Cunningham, C.W. (2009). Reconciling genealogical and morphological species in a worldwide study of the family Hydractiniidae (Cnidaria, Hydrozoa). Zoologica Scripta, 38 (4): 403-430.

Moura, C.J.; Cunha, M.R.; Porteiro, F.M. and Rogers, A.D. (2011). The use of the DNA barcode gene 16S mRNA for the clarification of taxonomic problems within the family Sertulariidae (Cnidaria, Hydrozoa). Zoologica Scripta, 40 (5): 520-537.

Naock, K.; Zardoya, R. and Meyer, A. (1996). The complete mitochondrial DNA sequence of the Bichir (Polypterus ornatipinnis), a basal ray-finned fish: Ancient establishment of the consensus vertebrate gene order. Genetics, 144 (3): 11651180.

Neafsey, D.E. and Palumbi, S.R. (2003). Genome size evolution in pufferfish: A comparative analysis of diodontid and tetraodontid pufferfish genomes. Genome Research, 13 (5): 821-830.

Noikotr, K.; Chaveerach, A.; Pinthong, K.; Tanomtong, A.; Sudmoon, R. and Tanee, T. (2013). RAPD and barcode analyses of groupers of the genus Epinephelus. Genetics and molecular research, 12 (4): 5721-5732.

Peng, Z.; He, S. and Zhang, Y. (2004). Phylogenetic relationships of glyptosternoid fishes (Siluriformes: Sisoridae) inferred from mitochondrial cytochrome b gene sequences. Molecular Phylogenetics and Evolution, 31 (3): 979-987.

Pepe, T.; Trotta, M.; di Marco, I.; Cennamo, P.; Anastasio, A. and Cortesi, M.L. (2005). Mitochondrial cytochrome b DNA sequence variations: an approach to fish species identification in processed fish products. Journal of food protection, 68 (2): 421-425.

Quraishia, S.F.; Panneerchelvam, S.; Zainuddin, Z. and Abd Rashid, N.H. (2015). Molecular characterization of Malaysian marine fish species using partial sequence of mitochondrial DNA $12 \mathrm{~S}$ and 16S rRNA markers. Sains Malaysiana, 44 (8): 1119-1123.

Randall, J.E. (1982). The Diver's Guide to Red Sea Reef Fishes. Publishing limited 20 Berkeley Street, Berkeley square London Wix 5AE, 96 pp.

Saad, Y.M. (2019). Analysis of $16 \mathrm{~S}$ mitochondrial ribosomal DNA sequence variations and phylogenetic relations among some Serranidae fishes. South African Journal of Animal Science, 49 (1): 80-89.

Saad, Y.M. and Abd El-Sadek, H.E. (2017). The efficiency of cytochrome oxidase subunit 1 gene (cox1) in reconstruction of phylogenetic relations among some crustacean species. World Academy of Science, Engineering and Technology International Journal of Animal and Veterinary Sciences, 11 (7), 515-520.

Sabrah, M.M.; El-Ganainy, A.A. and Zaky, M.A. (2006). Biology and toxicity of the pufferfish Lagocephalus sceleratus (GMELIN, 1789) from the Gulf of Suez. Egyptian journal of aquatic research, 32 (1): 283-297.

Singh, A.K.; Kumar, R.; Singh, M.; Mishra, A.K.; Chauhan, U.K.; Baisvar, V.S.; Verma, R.; Nagpure, N.S. and Kushwaha, B. (2015). Mitochondrial 16S rRNA 
gene-based evolutionary divergence and molecular phylogeny of Barilius spp. Mitochondrial DNA Part A, 26 (1): 41-47.

Song, L.; Liu, B.; Xiang, J. and Qian, P.Y. (2001). Molecular Phylogeny and Species Identification of Pufferfish of the Genus Takifugu (Tetraodontiformes, Tetraodontidae). Marine Biotechnology, 3 (4): 398-406.

Teletchea, F. (2009). Molecular identification methods of fish species: reassessment and possible applications. Reviews in Fish Biology and Fisheries, 19: 265-293.

Rosas, U.; Menendez, F.; Cornejo, R.; Canales, R. and Velez-Zuazo, X. (2018). Fish DNA barcoding around large marine infrastructure for improved biodiversity assessment and monitoring. Mitochondrial DNA Part A, 29 (8): 1174-1179.

Vinson, C.; Gomes, G.; Schneider, H. and Sampaio, I. (2004). Sciaenidae fish of the Caeté river estuary, Northern Brazil: Mitochondrial DNA suggests explosive radiation for the Western Atlantic assemblage. Genetics and Molecular Biology, 27 (2): 174-180.

\section{ARABIC SUMMARY}

\section{العلاقات الوراثية الجزيئية لأسماك الفهقة النيلية والبحرية باستخدام تتابع الحمض النووي للميتوكوندريا Cytochrome $b$ and 16S rRNA}

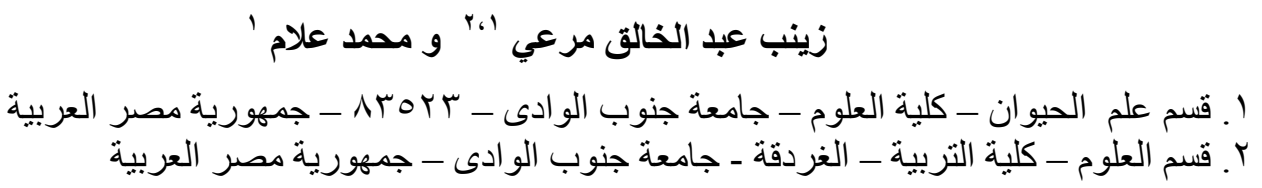

أجريت هذه الدر اسـة علي أسماك الفهقة النيلية Tetraodon lineatus - النوع الوحيد في نهر النيل

بمصر - و الفهقة البحريـ Arothron hispidus بهدف دراسـة العلاقات الور اثيـة الجزيئية بين أسماك الفهقة

النيلية و البحرية بمصر وذلك باستخدام اثنين من تتـابع الحمض النـووي للميتوكوندريـا (Cytochrome b) و (16S rRNA وقد أظهرت النتائج من خـلال البيانات المتوفرة في بنك الجينات GenBank أن طول تتابع

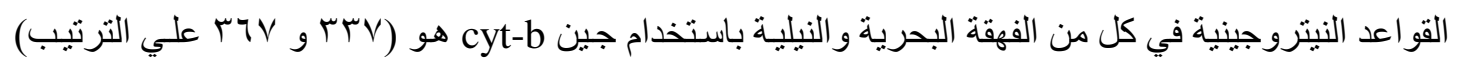

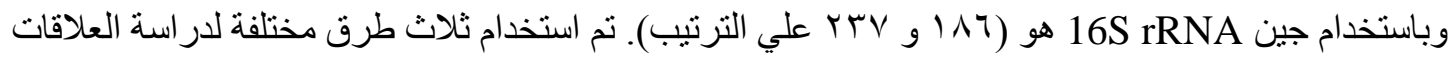

الور اثية الجزيئية هي (Maximum Likelihood) و Neighbour Joining و (Minimum Evolution)

$$
\text { لمقارنة النتائج علي نطاق واسع. }
$$

بشكل عام أوضح التحليل الإحصائي الدقيق للمسافات الور اثية بين الأنواع محل الدر اسـة باستحدام جينـي

(16S rRNA و cyt-b)

من جنسي Canthigaster و أكبر من التقارب الور اثي بين الفقهة النيلية Tetraodon lineatus و أسماك الفهقة البحرية الاخري. كما أن التشابه في نتائج جيني (16S rRNA و cyt-b) يؤكد مدي فاعليتهما

$$
\text { في دراسة العلاقات التصنيفة الور اثية المرتبطة بهذا النوع من الأسماك. }
$$

